New Zealand journal of industrial relations, 1991, 16, 233-246

\title{
Labour militancy and private contracting: public hospital ancillary services
}

\author{
John Stubbs*
}

This paper attempts to show that regional variations in the strength of labour force militancy can be an important factor in mediating the regional development of privatization. By taking the private contracting of New Zealand public hospital ancillary services as a specific case study, it is seen that, in some cases, labour militancy can lead to the elimination of private contracting. While acknowledging the need for further research on this issue, some tentative conclusions are drawn on the relevance of labour militancy to the privatization of public service provision in other social contexts.

\section{Introduction}

Since the election of the Labour Government in 1984, the New Zealand economy has undergone extensive economic restructuring. This has largely consisted of a comprehensive process of market deregulation and privatization of state sector industry. Subsumed under the term privatization has been the corporatization of many government departments, the selling of State assets, and the contracting out of some public services to the private sector (private contracting). Certain government provided services, typically those deemed to provide an essential social function, such as hospital care, are increasingly being contracted out to private sector operators. By contracting out a service, the government still remains the funder while the private sector becomes the provider of the service itself.

In times of growing government fiscal constraints, privatization policies appear attractive to policy makers as a means to reduce public expenditure. Whatever the validity or otherwise of this argument, privatization has often been accompanied by substantial job loss, reduced employment conditions and a deterioration in the levels of service provision. Not surprisingly, therefore, there has been much opposition, from service user groups and trade unions (PSA, 1989).

Regardless of the way privatization has been implemented, considerable variation exists in the extent to which it has occurred both between, and within, individual nationstates. Similarly, privatization has proceeded very unevenly between certain industries or sectors within industries. These observations raise the immediate question of why, and

* Department of Geography, Coventry Polytechnic. The author is indebted to Professor Peter Fielding, School of Social Sciences, University of California, Irvine, for his helpful comments on an earlier draft of this paper. A further note of thanks is extended to the referees and editors of the New Zealand journal of industrial relations for their advice and assistance in the preparation of this paper. The usual disclaimers apply. 
how, this uneven process occurs. This paper examines the effect that labour force militancy may have upon the contracting out of public hospital ancillary services between different hospital boards. Consideration is given to the possibility that an industrially militant labour force can inhibit the development of privatization policies.

The first section of the paper details the uneven extent of privatization between different hospital boards, and briefly describes the development of the process over time. The second part examines the rationale for labour force opposition to privatization in the particular case of hospital ancillary services, while a third section examines the policies adopted by the relevant trade union to combat the policy. In the fourth section, which forms a substantive part of the paper, attention focuses on some specific case studies that demonstrate the way in which labour force militancy in the workplace can affect the development of privatization. The concluding section highlights some of the results of the trade union campaign of opposition with regard to the future development of privatization of the public sector economy.

\section{Regional variations in the development of privatization}

Regional variations in the extent of contracting out public hospital ancillary services (domestic cleaning, orderly (portering) and dietary (catering) requirements) are shown in figure 1. The variations are given in respect of private contracting since 1975 in all (pre) existing 29 hospital boards. 1

There are basically 3 actors of interest in respect of explaining the geographical pattern that has developed. Without implying any order of significance, the first are the elected members of the hospital boards who represent local and regional community interests. These elected officials have the final decision on whether or not to privatize an ancillary service. Second, is the hospital management which is responsible for the administration of service provision. The managers are required to gain the approval of their respective hospital board members before making any major policy changes such as private contracting. The board members, in their turn, rely critically upon information supplied by hospital managers in making policy decisions. The third is the workforce employed to provide the services. In this case there is no direct input into policy formation. However, there is an indirect input, in the form of industrial unrest, which can arise if policies adopted are detrimental to workers' employment conditions.

A feature that is immediately apparent from the maps in figure 1 is the considerable variation in the regional pattern of contracting out over time. A detailed account of this is given elsewhere (Stubbs, 1990) but it is useful to detail some of the more important features. Private contracting for hospital ancillary services first developed after World War II in response to a severe labour shortage in the economy. By contracting out, hospital boards were spared the difficult administrative problems of staff recruitment and supervision. The initial success of contract service provision saw the process expand through the 1950 s and 1960 s.

For most of the $1970 \mathrm{~s}$, there was a period of relative stagnation in the process but, at the end of the decade, a much more complex pattern of privatization started to develop. Largely in response to the start of a series of central government restraints on hospital board expenditure, some boards which had hitherto been providing their own services (e.g. Auckland and Hawke's Bay), found that savings could be made by contracting out their ancillary services. Contractors claimed to be able to run services much more cost

1 By mid 1989, all hospital boards had been replaced by 14 area health boards. To provide comparison with earlier years, the original boundaries of the previous 29 hospitals boards have been maintained. Where in figure 1 a hospital board is shown as contracting out a service this does not necessarily mean that all hospitals within that board engage contractors. 
Figure 1: Ancillary services contracted out within hospital and area health boards

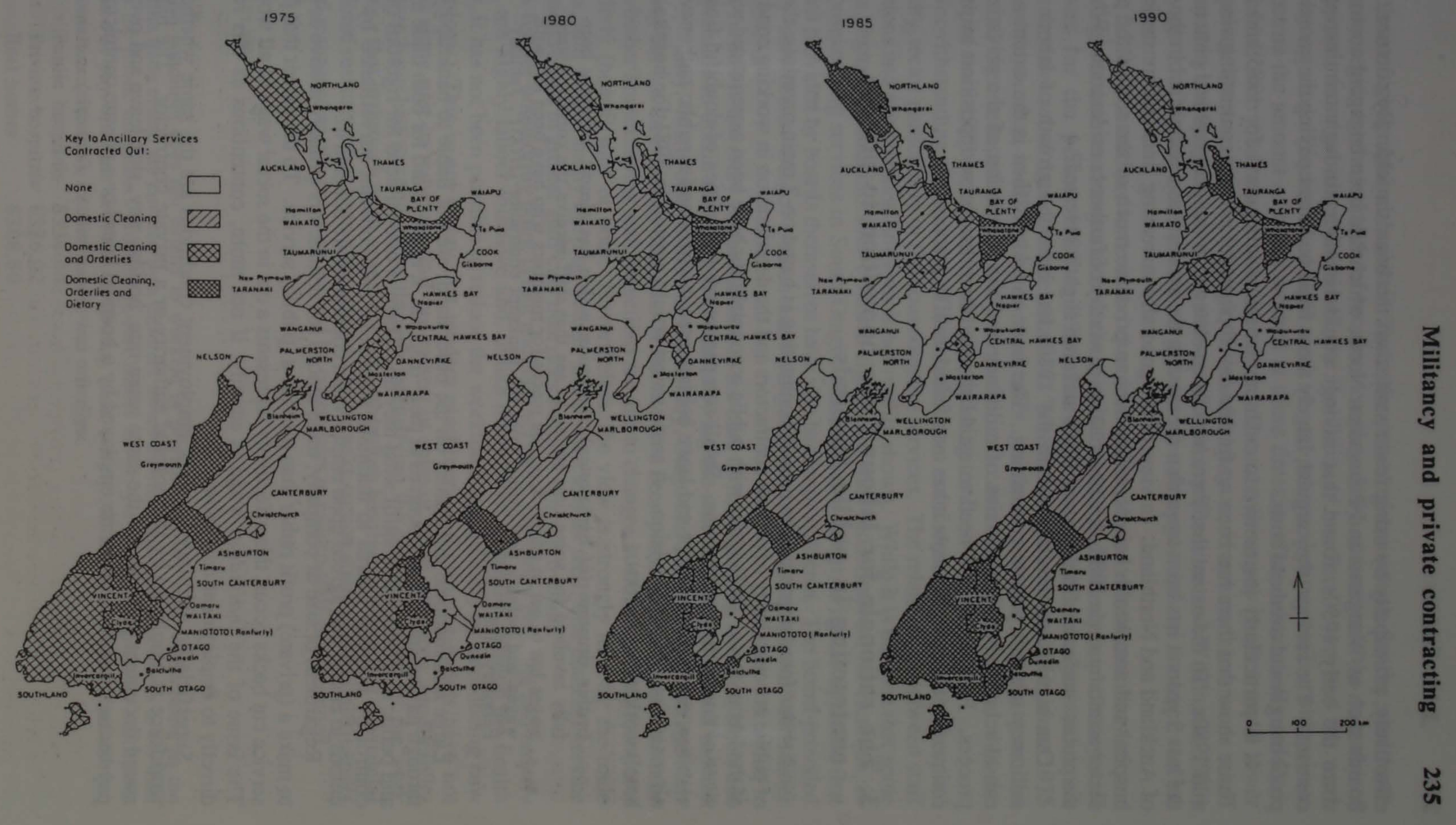


effectively, principally by using fewer staff, than the boards could. By contrast, other boards such as Wanganui and Palmerston North, which had been engaging contractors since the early $1950 \mathrm{~s}$, found that savings could be made through terminating the contracts. The savings, they argued, largely arose from no longer paying the contractor's profit margin and overhead costs.

It is particularly instructive to examine the maps in figure 1 for 1985 and 1990. These show that there has been no further development of private contracting since the mid 1980s. To the extent that there have been changes in the geographical pattern over the last 5 years it has been towards a decrease in the process, as exemplified in the cases of Auckland and Northland. In view of the generally increasing financial constraints on hospital and area health boards, and moves to privatize much of the rest of the public sector economy since 1985 , this observation is worthy of further consideration. Why has the process stagnated from the mid 1980 s and even slightly reversed?

One significant development in the 1980 s has been the growth of labour force militancy towards private contracting. The issue to address then is the extent of any causal relation between the rise of militancy and the stagnation of the privatization process. First, there is a need to establish why there has been opposition to private contracting and secondly how it has manifested itself in practice.

\section{The rationale for labour force opposition to private contracting in public hospitals}

Labour force opposition to private contracting is based on 2 main premises: the lack of public accountability of private contractors and the deterioration in working conditions of the labour force. Difficulties with public accountability have been experienced with all sizes of contracting companies. Small companies are sometimes of doubtful financial viability, easily go bankrupt and leave behind unpaid wages and a public authority with no means of service provision. A trade union article written in 1981 for hospital (and hotel) workers argued that:

In this situation (of bankruptcy), the union which has almost certainly been fully involved for some time trying to see that staff receive the correct Award wages has to get in and pick up the pieces for members who have been left with wages and holiday pay owing from the bankrupt contractor (HOSP, JanuaryFebruary, 1981, p.1).

Large multinational companies on the other hand, are not liable to bankruptcy but, through having such large resources at their disposal, it is very hard for both trade unions and public authorities to control what they do. There is often a need for rigorous quality control by hospital boards to maintain standards, and constant surveillance by trade unions to ensure that agreed upon employment conditions are adhered to.

Regardless of size of company, trade unions see contractors' primary motive as being to make a (private) profit rather than provide a (public) service. To the extent that public service cut backs occur, this effectively represents a cut in the social wage of all workers. The issue of the individual wage is equally, if not more, contentious as this relates directly to employment conditions.

Superficially, ancillary workers' employment conditions are the same whether the workforce is employed by the hospital authority or a private contractor. The national award document provides for the same wage rate, holiday pay, sick leave and overtime payments, whether workers are employed by a hospital board or a private contractor and 
regardless of geographical region. ${ }^{2}$ The main points of contention for the workforce primarily relate to the number of workers employed by contractors, the security of employment from arbitrary dismissal, the flexibility of workers' hours and the work intensity required. Weekend and night work attracts enhanced pay rates, but with private contractors the amount of hours worked at these times is often substantially reduced. Former full time jobs become part time ones. The take home pay is often much lower with private contracting even though the nominal pay rate remains the same as when employed by the hospital board. In a low paid industry (Brosnan and Wilkinson, 1989) this wage loss would be expected to generate much opposition to contract service provision.

A further contentious issue is the extent of staff reductions in the ancillary sector. Table 1 gives data on changes to housekeeping (domestic and orderly) and dietary staff numbers for the period 1980 to 1988 for those hospital boards from whom a comprehensive set of data could be obtained. Where data has been available since 1975 this has shown that, in all but a very few cases, numbers increased slightly to around 1980 and then reduced significantly thereafter. It cannot therefore be said that the reductions since 1980 merely continued a pre-existing trend.

Notwithstanding the sparsity of data, jobs have certainly been lost in the hospital ancillary sector particularly in the housekeeping services. The relationship between staff reductions and privatization however is not readily shown. While it is the case that some boards engaging contractors have shown significant staff reductions as, for example, in the housekeeping services in South Otago, Thames and Vincent, it is also apparent that services provided by boards themselves have also had large staff cuts. The board-provided dietary services in Otago, Nelson and Wanganui are prime examples of this latter situation.

A further noteworthy feature is that, in the case of housekeeping services, it has not been possible to obtain disaggregated data showing the number of cleaning and orderly staff separately. Many boards, such as Canterbury, Otago and Taranaki, contract out their cleaning but not their orderly services. It has not then been possible to ascertain from the data whether housekeeping staff reductions are due to changes in either cleaning (contract) or orderly (board) staff or both. Nevertheless, the view is strongly held by the trade unions, and indeed many hospital boards and contractors as well, that contract service provision results in greater staff cuts than does hospital board provision.

A further noteworthy point is that ancillary services, especially cleaning and orderly work, are highly labour intensive and, unlike many other industries outside the health sector, it has not been possible to reduce the workforce significantly by introducing new technology. This is not to say that modern machinery and cleaning agents have not played some part in reducing staff but rather, in spite of these advances, productivity increases have had to come more through intensifying the physical nature of the work process - that is through work speed-ups. It is therefore hardly surprising that substantial workforce resistance has been encountered. In the next section some of the consequences of, and resistance to, the pressure applied by contractors to reduce staff are examined.

2 This condition does not extend to workers in private hospitals who, while being in the same trade union, are covered by a different award in which the basic pay rate is lower than in the public hospitals. Workers in rest homes are on yet another award with still lower rates of pay. In June 1989, the following basic weekly (40 hours) pay rates obtained for, domestics (cleaners), kitchen hands, and orderlies:

Public hospitals \$334.44

Private hospitals $\$ 326.02$

Rest homes $\$ 308.60$ 
Table 1: Percentage changes to housekeeping and dietary staff numbers in hospital boards $1980-88$

\begin{tabular}{|c|c|c|}
\hline Hospital Board & Housekeepinga & Dietary \\
\hline Auckland & $-b$ & +1.3 \\
\hline Canterbury & -24.0 & $-b$ \\
\hline Otago & -38.2 & -20.5 \\
\hline Waikato & $-b$ & -12.4 \\
\hline Wellington & $-b$ & +5.1 \\
\hline Cook & -15.5 & -3.9 \\
\hline Hawke's Bay & -29.7 & -4.3 \\
\hline Nelson & -9.2 & -21.7 \\
\hline Northland & -b & $-b$ \\
\hline Palmerston North & -13.4 & $-b$ \\
\hline S. Canterbury & -7.9 & -2.3 \\
\hline Southland & -b $^{\mathrm{b}}$ & -7.0 \\
\hline Taranaki & -21.5 & +8.9 \\
\hline Tauranga & -5.1 & -6.5 \\
\hline Wanganui & -22.8 & -23.1 \\
\hline West Coast & -10.3 & -16.8 \\
\hline Ashburton & -39.3 & $-b$ \\
\hline Bay of Plenty & -26.0 & $-b$ \\
\hline C. Hawke's Bay & -23.4 & -8.1 \\
\hline Dannevirke & -7.7 & +35.2 \\
\hline Maniototo & 0 & -26.7 \\
\hline Marlborough & $-b$ & -12.1 \\
\hline South Otago & -53.6 & -18.1 \\
\hline Taumarunui & $-b$ & +4.7 \\
\hline Thames & -32.0 & $-b$ \\
\hline Vincent & -40.0 & -1.5 \\
\hline Waiapu & -26.3 & -15.7 \\
\hline Wairarapa & -3.5 & +11.1 \\
\hline Waitaki & -42.9 & -10.3 \\
\hline
\end{tabular}

Source: Hospital/area health boards and hospital management data

Notes: a Housekeeping comprises an aggregate of domestic cleaning and orderly services.

b Insufficient data.

\section{Trade union policy and contracting out ancillary services}

A campaign of industrial action against contract employment developed in the $1980 \mathrm{~s}$ but this policy must also be seen as part of a broader campaign to involve the workforce 
in trade union affairs and the maintenance of the public hospital system. In the words of a prominent official of the Hotel and Hospital Workers' Union:

The whole drive was to bring the union back to the members. If they felt an action by an employer was unjust, they had to decide: does it go to court again or should they take direct industrial action. We advocated a direct response to injustice rather than waiting for the legal system to take effect.

We also improved communications with members. We started a union newspaper, published a training manual, hired an education officer, elected more delegates and got all of them more involved with the decision making process (Metro, September 1989, p.116).

In order to see whether there was a regional variation in the effectiveness of this campaign, an attempt was made to find out which hospital board districts have had the most industrially militant ancillary workforces and relate this militancy to the regionally uneven development of private contracting. Work stoppages, whether complete (i.e. strikes) or partial (i.e. work bans on selected duties) may arguably be the most obvious surrogate of labour militancy or class conflict. Unfortunately, officially published statistics on this measure are not sufficiently disaggregated to include public hospitals.

To gain data on this subject, a survey was conducted of the industrial action taken by ancillary workers across the entire country. Initially it was hoped to gather data relating to the number of working days lost per annum per employee, to measure quantitatively the levels of industrial militancy in each hospital board district. Unfortunately, a sparsity of trade union records prevented such a comprehensive set of data being collated. It was however still possible to determine where and when the most prolonged industrial action took place. It can be seen from table 2 that major strike action lasting more than a week has been confined exclusively to the Northland, Auckland and Wellington Hospital Boards and all occurred in the 1980 s. This, however, is not to deny the existence of widespread industrial action throughout the decade in other boards. Moreover, as table 2 shows, the industrial action has not just been over private contracting, but also over matters like the breakdown of national wage negotiations.

In respect of industrial action specifically related to private contracting, the important point, as will be seen presently, is that only in Auckland and Northland has it been sustained over a long period of time. In order to gain a perspective on the way in which labour force militancy impacted upon the geographical development of private contracting in the ancillary sector a comparative study was made of 4 hospital boards that adopted opposing policies for ancillary service provision.

\section{Contracting out and labour militancy: case studies}

It is instructive to compare the form of ancillary service provision in Northland and Auckland with the Southland and Otago boards. Auckland and Otago contracted out their domestic cleaning services in 1981 and 1982 respectively. Southland and Northland contracted out their dietary services in 1983 and 1985 respectively. All 4 cited cost savings as being the prime reason for contracting out. While Otago and Southland have retained contract provision, Auckland reverted to in-house provision in 1988, and in the same year Northland terminated its dietary contract, although contract provision for housekeeping services was retained. The question then is why the 2 northern boards changed their policy and not the southern 2 ?

In the first place, it is pertinent to note that these 4 hospital boards are of approximately equal size whether considered on the basis of bed numbers or populations served. Although the population and bed numbers of the Auckland Board are much greater than Otago, compared to other boards in the country these are in the same size category in as much as they each have over 1,000 beds, offer highly specialized services, 
and have medical schools. It cannot therefore be argued that one board might have achieved scale economies by contracting out services and not the other.

Table 2: Principal work stoppages in public hospitals by members of the Hotel and Hospital Workers' Union

\begin{tabular}{|c|c|c|c|c|}
\hline $\begin{array}{l}\text { Hospital } \\
\text { Board }\end{array}$ & Year & $\begin{array}{l}\text { Staff } \\
\text { category }\end{array}$ & $\begin{array}{l}\text { Employer at } \\
\text { time of work } \\
\text { stoppage }\end{array}$ & $\begin{array}{l}\text { Duration } \\
\text { of strike }\end{array}$ \\
\hline Otago & 1974 & domestic & contractor & 1 day \\
\hline Otago & 1980 & domestic & hospital board & 2 days \\
\hline Wellington & 1981 & domestic & contractor & 4 weeks \\
\hline Auckland & 1983 & domestic & contractor & 6 weeks \\
\hline Various Boards & 1985 & all categories & $\begin{array}{l}\text { State } \\
\text { (Award breakdown) }\end{array}$ & various \\
\hline Wellington & 1985 & orderlies & hospital board & 12 days \\
\hline $\begin{array}{l}\text { West Coast } \\
\text { (Greymouth) }\end{array}$ & 1985 & $\begin{array}{l}\text { domestic and } \\
\text { orderlies }\end{array}$ & contractor & 2 weeks \\
\hline $\begin{array}{l}\text { Northland } \\
\text { (Whangerei) }\end{array}$ & 1986 & dietary & contractor & 4 weeks \\
\hline Palmerston N. & 1986 & domestic & hospital board & 2 days \\
\hline Ashburton & 1986 & orderlies & contractor & 4 days \\
\hline Various Boards & 1986 & all categories & $\begin{array}{l}\text { State } \\
\text { (Award breakdown) }\end{array}$ & various \\
\hline Various Boards & 1987 & all categories & $\begin{array}{l}\text { State } \\
\text { (Award breakdown) }\end{array}$ & 2 days \\
\hline Various Boards & 1988 & all categories & State Sector Bill & 1 day \\
\hline Various Boards & 1989 & $\begin{array}{l}\text { all categories } \\
\text { ( }+ \text { nursing staff) }\end{array}$ & $\begin{array}{l}\text { State } \\
\text { (Award breakdown) }\end{array}$ & 1 day \\
\hline
\end{tabular}

Source: Regional offices of the Hotel and Hospital Workers' Union

A similar lack of explanatory significance holds in respect of the relative degree of central government financial constraint on these boards. While not readily quantifiable, crude level of financial constraint may be taken to be: 


\section{Government financial allocation \\ Hospital board district population}

Table 3: Financial constraints on Auckland, Northland, Otago and Southland hospital boards

Government financial allocation in dollars per capita in 4 hospital boards

Hospital

board

1981

1986

Auckland

194.2

325.7

Otago

311.5

483.7

Northland

222.9

347.5

Southland

206.6

336.8

Source: Stubbs (1990) p.207.

From this formula it is possible to determine the financial allocation per capita for each board under consideration, and the data is given in table 3 for the census years 1981 and 1986. It can be seen from table 3 that Northland and Southland were under very similar levels of financial constraint in both 1981 and 1986. Otago, however, was considerably less financially constrained than Auckland in both years. If contracting out is seen principally as a means of making economic savings, then the change in service provision might more readily be expected in Otago than in Auckland. Tighter financial constraint in the case of Auckland would be a stimulus to maintain the contract provision.

There remain, though, substantial differences between the northern and southern 2 boards in terms of political and managerial factors and in industrial relations in the ancillary sector. These are discussed in greater detail in the following sections.

\section{Labour force militancy in Auckland and Northland: the implications for contracting out}

Higher levels of industrial disruption in the ancillary services of the Auckland and Northland Boards provide an immediate point of contrast with Otago and Southland. Both Auckland and Northland were the scenes of 2 highly protracted work stoppages. At the end of 1983, there was a 6 week strike of domestic cleaners employed by Crothalls Ltd $^{3}$ at Auckland Hospital. In early 1986, the dietary service workers employed by Advanced Food Services Ltd, a subsidiary company of Crothalls, took strike action lasting 4 weeks in all the hospitals in the Northland district. This strike action was preceded by 9 weeks of limited industrial action.

3 Crothalls Ltd became known as United Health Serv(NZ) in 1989 and the company formed a subsidiary of the American based multinational ADT services (American District Telegraph). 
By comparison, the industrial scene in Otago and Southland has been characterized by disputes on a much smaller scale both in terms of duration and numbers of workers involved. While limited industrial action by workers under contract employment was quite extensive in Otago (Otago Daily Times, 26 June 1984; 3 September 1985), no prolonged disruption occurred in either board, and complete stoppages (i.e. strikes) were restricted to just a few days at the most. In the Southland Board, strikes were sometimes just confined to workers on 1 particular shift rather than all within the entire service. So, while there was certainly resistance to the conditions of work under contract employment, particularly in Otago, the campaign appears to have been less intense than in Auckland and Northland.

In Auckland, the domestic cleaners' strike began after the contract had been in operation for 27 months and staff numbers had been reduced from 182 at the commencement of the contract to 105.4 Crothalls cited a reduction to 102 although no independent verification of any of these figures was available. The company justified this reduction on the grounds that, "the productivity rate of the Auckland Cleaners is lower than that which exists in our other 46 contracts". 5 but no indication was presented as to how the productivity rate was calculated. The considerable time that elapsed between the commencement of the contract and the industrial action may largely be attributed to the degree of organization and trade union consciousness that had to be established amongst the work force.

The prime reason for the strike was to achieve increases in staffing levels in order to combat falling service standards and increased workloads, since attempts to realize this through negotiation were seen by the union to have failed. 6 After 6 weeks a government appointed industrial conciliator ordered the strikers back to work with the condition that Crothalls had to employ an extra 6 workers and replace 1 who had left (SHIFT, AprilMay 1984, p.3). The strike, therefore, simply altered, as was intended, the conditions of service provision rather than the form of provision, and another 5 years elapsed before the contract itself was terminated.

The cause of the industrial action in Northland was mainly over the principle behind the letting of the contract for the dietary services without there being any prior consultation between the workers involved and the Northland Area Health Board. It is this factor which largely explains why the focus of trade union attention was on the dietary services rather than the housekeeping. The latter had been under contract since about the mid 1950s and so, unlike dietary services, there had been no sudden change in the form of service provision. Rather than specifically seeking an improvement in the conditions of employment, the strike was more in anticipation of reduced staffing levels and lower standards of service provision under contract. The prime purpose of the strike was to have the contract cancelled and a return to service provision by the Board. The strike itself had been preceded by a period of limited action from 18 November 1985, the date of commencement of the contract, to January 191986 ( 9 weeks) after which there was a complete work stoppage to 15 February 1986.

Shortly prior to the end of the strike, a meeting between the Hotel and Hospital Workers' Union, the Federation of Labour and the Employers' Federation proposed that a committee of enquiry be formed to investigate the way in which, "the contract was let, the lack of consultation [with the union] and the appropriateness of the contract" (SHIFT, April-May 1986, p.11). On this basis, a High Court injunction was issued ordering a return to work. The strike, however, did not succeed in terminating the contract and instead, the formation of a committee of enquiry was the immediate outcome.

These major strikes, however, were only the most visible part of the trade union campaign against the contractors in these 2 boards. Apart from these, there were also, in 
the case of Auckland at least, numerous strikes of shorter duration while in Northland workers adopted, "a non-cooperation attitude to the contractors"7 which meant, for example, that workers would collectively refuse to undergo changes in either their hours of work, the areas in which they were to work, or the duties required of them. Independent consultation with Northland Board management has subsequently confirmed the extent and effectiveness of much of the non-cooperation campaign.

The effect of this campaign was that, "no moves could be made by AFS [Crothalls] to implement changes which would result in profit making for the company".8 Similarly in Auckland, non-cooperation strategies made it very difficult to implement all the cost cutting measures deemed necessary by the contractor. For example, Crothalls cite the case of night workers being unwilling to transfer to day shift and, "all pressures we have applied to move this group have met with union involvement by way of support for their members". 9

The central question then is to ascertain the precise linkage between the industrial disruption that took place and the action of the 2 boards in terminating the contracts. This necessitates examining the roles of the hospital and area health boards' management (appointed) and membership (elected) structures in the context of the trade union campaign. In the next section the attitude of hospital management staff in Auckland and Northland is considered and, where appropriate, comparisons are drawn with the Otago and Southland boards.

\section{The management of ancillary services in the Auckland and Northland boards}

It might reasonably be expected that the boards' management staff would be highly opposed to having placed upon them the employment of such a militant labour force. For this very reason, managers would have wanted to continue with contract provision. However, from the proposals made by the management to the board members this was not the case. According to the available records, in all 3 hospitals in the Auckland Board where contractors were engaged - Auckland, North Shore and Sutherland, the respective hospital managers advocated the termination of the contracts in their reports to the board membership. The justification presented for recommending the termination of the contracts was based primarily on the inadequacy of standards of service provision and the costs involved with this form of provision.

Of the 3 contractors who submitted tenders for Auckland Hospital in 1987, 2 were thought by management to be insufficiently resourced to ensure an adequate and reliable service. The third contractor, which was the incumbent Crothalls, was deemed to have submitted the most realistic tender and the company cited 3 possible options for the board. The most economical of these required the elimination of rotating shifts. In an internal memorandum of 11 November 1987 to the board's chief executive, the executive officer, hotel services wrote, "Such changes may cause adverse reaction from staff, it would affect thirty nine people, possibly creating more industrial action (my emphasis)". This point however was not made in the report to the board membership. Instead, the management submitted a proposal detailing how the service could be provided more economically by the board. This would be achieved by reducing what were thought of as the contractor's excessive allowances for, "sick pay, annual leave and the miscellaneous insurances".10

10 Management Report to Auckland Hospital Board, 30 November 1987. 
Despite the formal justification for contract termination on financial grounds, the possibility of further industrial disruption and consequent suspension of service appears an important factor in the recommendation of board (public) provision. For both North Shore and Sutherland hospitals, the stated reason in management reports for reverting to board provision was based more on poor standards of service than industrial action. North Shore management reported that, "The present staff of approximately 23 full time equivalent persons is barely adequate to maintain a satisfactory cleaning standard, ${ }^{11}$ but mention was also made that the Hospital Workers Union, "has indicated its willingness to cooperate closely with the Board to ensure the maximum possible flexibility, effectiveness and efficiency". The clear implication is that the workforce did not cooperate closely with the contractor, and this doubtless adversely affected the standard of service.

For the Northland Board, the management argued that, by terminating the dietary service contract, cost savings would arise:

through not having to pay a salary for the Base Hospital food services manager $(\$ 36,500$ p.a.), a pay clerk's salary $(\$ 20,000$ p.a.) and an estimated profit of $\$ 104,000$ p.a., [and] elimination of excess wastage of food would result in savings of at least $\$ 94,000$ per year. 12

Significantly, however, the Board minutes also made the following observation in support of the termination of the contract:

The Personnel Manager has commented that the Board spends more time settling kitchen labour relations issues than it does for any other section of Board staff, and in the event of strike action it has been the Board's staff who have taken total responsibility for organising volunteers. ${ }^{13}$

Even more pertinent, however, to the termination of the contract, and confirmed from discussion with Board management, was the agreement of the trade union to end its noncooperation policy. A written communication of 7 October 1988 from the Hotel and Hospital Workers' Union to the Northland Board general manager highlights this point and is quoted at length in view of its importance:

The situation should Advance Foods be contracted to continue to run the kitchens in Northland will mean that previous agreements made between that company and this union would prevail. These agreements thrashed out during the period of that dispute are quite clear in guaranteeing the continued privileges of all those workers in respect to rosters, the ability to maintain their level of earnings and the other conditions they had enjoyed whilst employed by the Area Health Board previously. We believe, having discussed with those members the current situation, that they have much to offer the Board in the way of efficiencies and economies for the future. That level of co-operation would be available should the Board decide to take back the employment of our workers.

Should, however, the contract go to Advanced Foods or any other contractor, clearly that level of co-operation from those members would be very difficult to deliver. 14

11 Management Report to Auckland Hospital Board, 16 March 1987.

12 Management Report to Northland Area Health Board, 3 October 1988.

13 Management Report to Northland Area Health Board, 3 October 1988.

14 Written communication from the Hotel and Hospital Workers' Union to the Northland Board General Manager, 7 October 1988. 
This passage, and the earlier quotes, make clear that while economic (i.e. cost savings) or managerial (i.e. standards of service) arguments could be presented for terminating contracts, underpinning both of them was the desire by the boards to end industrial disruption and gain workforce cooperation. With the case of Auckland, however, a further factor to be considered in the contract termination was the workforce involvement with the elected board membership. Curiously, this involvement went much further in Auckland than Northland to say nothing of Otago and Southland.

\section{Political factors in the termination of contract services in the Auckland Hospital Board}

The composition of the Auckland Hospital Board has been unique through the election in 1986 of members of a Community Health Coalition. This was specially formed in, "an effort to get worker representatives onto the Hospital Boards throughout the Northern Region [of the Hotel and Hospital Workers Union]" (SHIFT, AugustSeptember 1986 , p.5). The policy was largely born of a view held by many trade unionists that existing hospital board members had very little interest either in maintaining a comprehensive public health system or in the employment conditions of many of its workers, particularly in the face of mounting pressures to expand privatization policies in all other areas of the hospital service.

According to SHIFT (April-May 1986, p.7), the newspaper of the Northern Region of the Hotel and Hospital Workers' Union, the main aims of the Coalition were, "to support a free, public health system and to elect people to the board who are prepared to pressure local government to ensure this happens". More specifically, a major concern of the Coalition was, "the way staff are treated at the hospital - orderlies, domestics, kitchen workers and nurses do not get a good deal". The removal of contractors from the hospital system was clearly a principal objective of the industrial campaign.

Of the 8 people who formed the Coalition, 4 gained seats on the 14 person board in the October 1986 election. The Board itself was structured into 6 committees of which the Finance and General Purposes Committee was the one which handled issues related to contract service provision and received reports from the board management staff on this issue. Six people served on this committee, 2 of whom were from the Community Health Coalition and 1 of these was a member of the Hotel and Hospital Workers Union employed at Auckland Hospital. All policy decisions had to be approved by this committee before being passed by a full meeting of all Board members. The Coalition members were not therefore in a majority position on this committee but certainly had a platform from which to make their views known and to present arguments for termination of the contracts.

As seen above, the reports from the management recommended, even if not particularly persuasively, that board provision be reverted to. It is hardly surprising then that the contract was terminated. Nevertheless it is clear from the arithmetic of the board membership alone that the 4 other members of the Finance Committee, none of whom had any trade union connection, could have out voted the 2 from the Coalition and overturned the management's recommendation had they been so inclined. An argument that the changed form of ancillary service provision in Auckland was purely the result of the election of a special interest group cannot readily be sustained although this was undoubtedly an important factor.

To summarize the situation, 3 factors seem to have operated in conjunction with each other in securing the termination of the Auckland Board contracts. First has been that of a militant, organized workforce likely to create further service disruption if placed under greater pressure from the contractors. The prospect of greater industrial tranquility therefore made a return to board provision look more attractive from a management perspective even if difficult to justify financially. The second factor then has been a 
management structure prepared to undertake further administrative responsibility albeit with a guarantee of workforce cooperation and a less traumatic climate of industrial relations.

The third factor involved, comes from the observation that neither the workforce, no matter how militant, nor the management, no matter how firm in their policy proposals, have the final say in policy decision making. This duty falls to elected members of the Board. To this end, the gaining of political power by workforce representatives has been an important factor in bringing about the end of contract service provision. Yet this political power has only been founded on the basis of on-going industrial action. None of the 3 factors just cited here has operated so forcefully in Otago and Southland where, by contrast, the industrial disruption was less protracted although by no means nonexistent. There were no worker representatives elected to either of these 2 boards and no management proposals advanced for contract termination.

\section{Conclusion}

The case studies of the Auckland and Northland hospital boards have shown that a high level of industrial militancy can overturn privatization policies. In general though, the extent of ancillary service provision by private contract has remained largely unchanged across since the mid 1980s as is evident from the maps in figure 1 . Yet the foregoing analysis shows that, in some cases at least, industrial militancy has had a mediating effect on the development of privatization in different regions. Although more empirical research on this factor in other social contexts is certainly required, some further tentative conclusions can still be drawn.

Where the industrial action is short lived and sporadic, hospital managers can find their interests better served by continuing with private contracting rather than having the administrative burden of managing ancillary sector workers. On the other hand, with major industrial disruption, managers can no longer wash their hands of the situation and must instead consider active involvement in service provision. These observations could have considerable bearing on the possible future development of public service provision in the 1990s. As this paper has shown, privatization need not be accepted as a fait accompli by service user and worker organizations, and can be opposed successfully. However, the effectiveness of opposition requires a strong degree of commitment and solidarity from the people directly affected. Once established, privatized service provision is exceedingly difficult, although clearly not impossible, to remove. From the standpoint of state sector managers, it is apparent that, in certain cases, whatever the economic merits or otherwise, privatization can present highly intractable managerial problems in terms of service disruption and labour relations.

\section{References}

Brosnan, P. and Wilkinson, F. (1989) Low pay and industrial relations: the case of contract cleaning. New Zealand journal of industrial relations 14 (3): 83-89.

PSA (1989) Private power or public interest? Palmerston North, Dunmore.

Stubbs, J. (1990) Towards a theory of geographically uneven privatisation: the case of New Zealand public hospital ancillary services. Ph.D thesis, University of Canterbury. 